\title{
Geological age of the Ayukawa Formation (Oshika Group) in the South Kitakami Belt, Northeast Japan based on the ammonoids
}

\author{
Masayuki Ehiro*, \\ Miguel Company**, \\ Yukihiro Takaizumi*** and \\ Shun-ichi Hanamatsu ${ }^{* * * *}$ \\ Received November 8, 2019 \\ Accepted June 18, 2020 \\ * The Tohoku University Museum, Tohoku \\ University, Sendai 980-8578, Japan \\ ** Departamento de Estratigrafía y Paleon- \\ tología, Facultad de Ciencias, Universidad de \\ Granada, Campus de Fuentenueva s/n, 18002 \\ Granada, Spain \\ *** Michinoku Amateur Paleontologist' Club, \\ 1-9-1 Shouryou, Sendai 981-3108, Japan \\ **** Miyagi Prefectural Sendai Nika Senior High \\ School, 1-4-1 Renbou, Sendai 984-0052, Ja- \\ pan
}

Corresponding author: M. Ehiro, masayuki.ehiro.d4@tohoku.ac.jp

\begin{abstract}
Four ammonoid species, Olcostephanus atherstoni, $O$. cf. stephanophorus, Busnardoites aff. campylotoxus and Neocomites? sp. are described from the uppermost part of the Futawatashi Shale Member of the Ayukawa Formation distributed in Ajishima Island, Oshika Area, South Kitakami Belt, Northeast Japan. The age of this ammonoid fauna likely corresponds to the middle part (Neocomites neocomiensiformis Zone) of the early Valanginian, Early Cretaceous. According to our taxonomic re-examination of ammonoids previously reported from the Kobitawatashi Sandstone and Shale Member, and from the lower part of the Futawatashi Shale Member, the boundary between the Kobitawatashi and Futawatashi members correlates approximately with the Berriasian/Valanginian boundary. The starting time of the intense volcanic activity in the Oshika Area, represented by the deposition of the Yamadori Formation overlying unconformably the Ayukawa Formation, is considered to be late Valanginian to early Hauterivian.
\end{abstract}

Key words: Ayukawa Formation, Early Cretaceous, Oshima Orogeny, South Kitakami Belt, Valanginian ammonoid

\section{Introduction}

The Northeast Japan, including the South Kitakami Belt, suffered from a severe tectonic movement, the Oshima Orogeny (Kobayashi, 1941), during the Early Cretaceous. This orogeny began from a widespread intense volcanic activity along the "Kitakami Massif Eastern Margin-Rebun Volcanic Zone” (Kimura, 1979), and thick volcanic and volcaniclastic rocks covered the earliest Cretaceous and/or the pre-Cretaceous strata (e.g., Editorial Committee of Tohoku, 1989; Tsuchiya, 2017). Next, these strata, including the Early Cretaceous volcanics, were strongly folded and faulted, and finally, vast granitic plutons intruded over the entire area of Northeast Japan (e.g., Ehiro, 2017).

The ending period of the Oshima Orogeny is clearly defined to be Aptian, because isotopic ages of granitic rocks in the Kitakami Massif are mostly in a range of 110 to $135 \mathrm{Ma}$, concentrating around $120 \mathrm{Ma}$ (Shibata et al., 1978; Tsuchiya et al., 2015; Osozawa et al., 2019), and one of them (the Miyako Granite) is covered unconformably by the upper Aptian-lower Albian Miyako Group (Matsumoto, 1953, 1963; Hanai et al., 1968). On the other hand, the detail of the beginning time of the intense volcanic activity is not clear. Although some isotopic ages have been calculated on the Early Cretaceous volcanic rocks in the Kitakami Massif, they are nearly equal to or sometimes younger than those of granitic rocks, which intrude into the volcanics, suggesting the large possibility that these ages were altered (e.g., Tsuchiya et al., 2015). Moreover, the occurrence of ammonoids or other age-diagnostic fossils are rare in the lowermost Cretaceous strata which underlie the volcanics.

In the Oshika (Ojika) Peninsula at the southern end of the Kitakami Massif, the Middle Jurassic to lowermost Cretaceous Oshika Group is widely distributed (Fig. 1), and the Ayukawa Formation, uppermost formation of the group, is covered unconformably by the Early Cretaceous andesitic to basaltic volcanic and volcaniclastic rocks (the Yamadori Formation). The lower to middle part of the Ayukawa Formation yielded Berriasian ammonoids (Takizawa, 1970), and is important to elucidate the age of the covering volcanics and the starting time of the Oshima Orogeny.

In 1987 some ammonoids were collected in association with some crustaceans from the uppermost part of the Futawatashi Shale Member (upper part of the Ayu- 


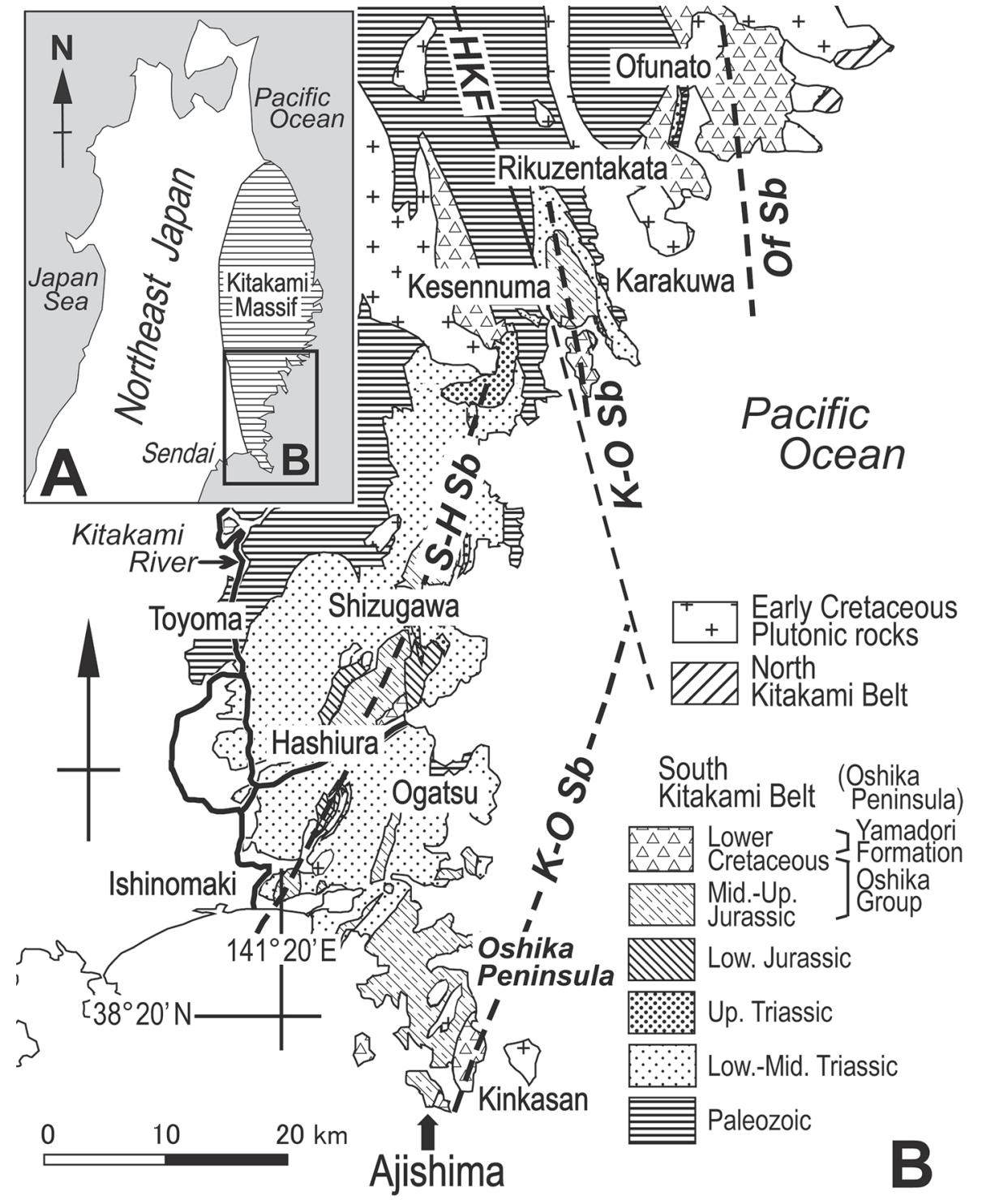

Fig. 1. Index map (A) and simplified geologic map of the Southern Kitakami Massif (South Kitakami Belt), Northeast Japan, showing the location of Ajishima Island (B) $H K F=$ Hizume-Kesennuma Fault; $\mathrm{K}-\mathrm{O} S b=$ Karakuwa-Oshika Sub-belt; Of $S b=$ Ofunato Sub-belt; $S-H S b=$ ShizugawaHashiura Sub-belt. kawa Formation) cropped out at the southern coast of Ajishima Island off Ayukawa (Fig. 1). Koseki et al. (1988, 1991) reported these ammonoids as Lyticoceras sp. and Olcostephanus sp., and correlated the ammonoid horizon with the Valanginian. But these ammonoids have not hitherto been described.

We re-examine and describe this Ajishima ammonoid fauna, together with additional materials recently collected by us. This paper also reviews the taxonomic assignment of some previously reported ammonoids from the lower to middle part of the Ayukawa Formation, and discusses the ages of the Ayukawa and Yamadori formations.

\section{Stratigraphic note on the Ayukawa Formation and the ammonoid horizon}

The Mesozoic strata of the South Kitakami Belt, which distribute in the southern part of the Kitakami Massif and the eastern margin of the Abukuma Massif, form three large synclinal structures (Fig. 1): the Shizugawa-Hashiura (Western) Subbelt, Karakuwa-Oshika (-Soma) (Central) Subbelt and Ofunato (Eastern) Subbelt (Takizawa, 1977). The Jurassic to Lower Cretaceous strata in the Oshika Peninsula, belonging to the Karakuwa-Oshika Subbelt, comprise the Middle Jurassic-lowermost Cretaceous Oshika Group and the Lower Cretaceous Yamadori Formation. The Oshika Group is divided into the Tsukinoura, Oginohama and Ayukawa formations in ascending order (Takizawa et al., 1974). Takizawa et al. (1974) subdivided the Ayukawa Formation into four members: the Kiyosaki Sandstone (640 m thick), Kobitawatashi Sandstone and Shale (400 m), Futawatashi Shale $(620 \mathrm{~m})$ and Domeki Sandstone ( 600 m) members, in ascending order. Takizawa et al. 


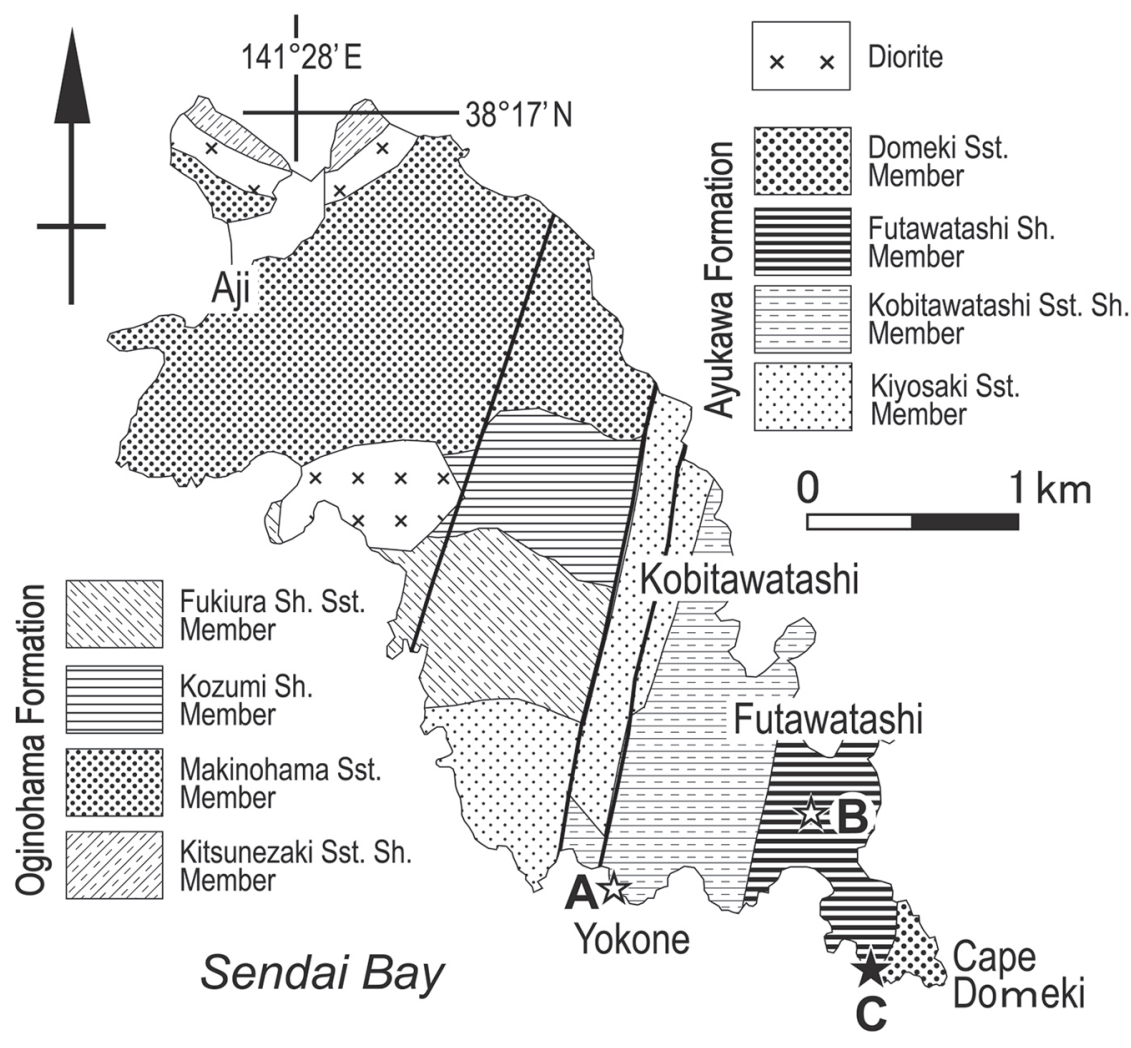

Fig. 2. Geologic map of Ajishima Island (simplified from Takizawa et al., 1974), showing ammonoid localities A-C. Sst $=$ sandstone; Sh $=$ shale .
(1974) considered that the Jurassic/Cretaceous boundary may exists near the boundary between the Kiyosaki and Kobitawatashi members, based on the ammonoids reported from the Kobitawatashi Sandstone and Shale Member (Takizawa, 1970). The Yamadori Formation covers the underlying Domeki Sandstone Member of the Ayukawa Formation with remarkable clinounconformity and is composed of volcanic and volcaniclastic rocks, about 1,600 m thick (Takizawa et al., 1974). Shibata et al. (1978) reported a K-Ar age (106 Ma) for the volcanic rock.

In the Oshika Peninsula, Early Cretaceous intrusive rocks and plutonic rocks are widely distributed intruding into or thermally affecting the Oshika Group and the Yamadori Formation. Large bodies are the Ojika Gabbroic Complex and Kinkasan Granite. The Ojika Gabbroic Complex distributes in the central part of the peninsula and consists of pyroxenite, gabbro, diorite and quartz diorite (Igi et al., 1974; Kubo 1977). They intrude into the Jurassic strata and are dated as $120 \mathrm{Ma}$ (Kawano and Ueda, 1964: K-Ar age). The Kinkasan Granite occupies the Kinkasan Island and is composed of granodiorite and quartz diorite. Its K-Ar ages are 112 and 122 Ma (Kawano and Ueda, 1964) and zircon U-Pb ages are 121 and 122 Ma (Tsuchiya et al., 2015).

Koseki et al. (1988, 1991)'s ammonoid locality is in the southeastern margin of Ajishima Island, west to
Cape Domeki (Fig. 2, Locality C), where the Futawatashi Shale Member and the Domeki Sandstone Member crop out dipping steeply to southeast. Their ammonoid specimens (IGPS coll. cat. no. 112392, 112394-112396) and our additional ones (IGPS coll. cat. no. 112393, 112397), in association with some ill preserved bivalves, were all collected from nearly massive mudstone of the uppermost part of the Futawatashi Shale Member at a horizon about $10 \mathrm{~m}$ below the base of the overlying Domeki Sandstone Member (Fig. 3).

\section{Systematic description}

All specimens described here are kept in the Tohoku University Museum (Institution abbreviation: IGPS = Institute of Geology and Paleontology, Tohoku University, Sendai). The following abbreviations are used in the descriptions: $D=$ diameter, $H=$ height of whorl, $W$ = width of whorl, $U D=$ diameter of umbilicus.

Order Ammonitida Agassiz, 1847

Suborder Ammonitina Agassiz, 1847

Superfamily Perisphinctoidea Steinmann, 1890

Family Olcostephanidae Haug, 1910

Subfamily Olcostephaninae Haug, 1910

Genus Olcostephanus Neumayr, 1875

Type species: Ammonites astierianus Orbigny, 1840 


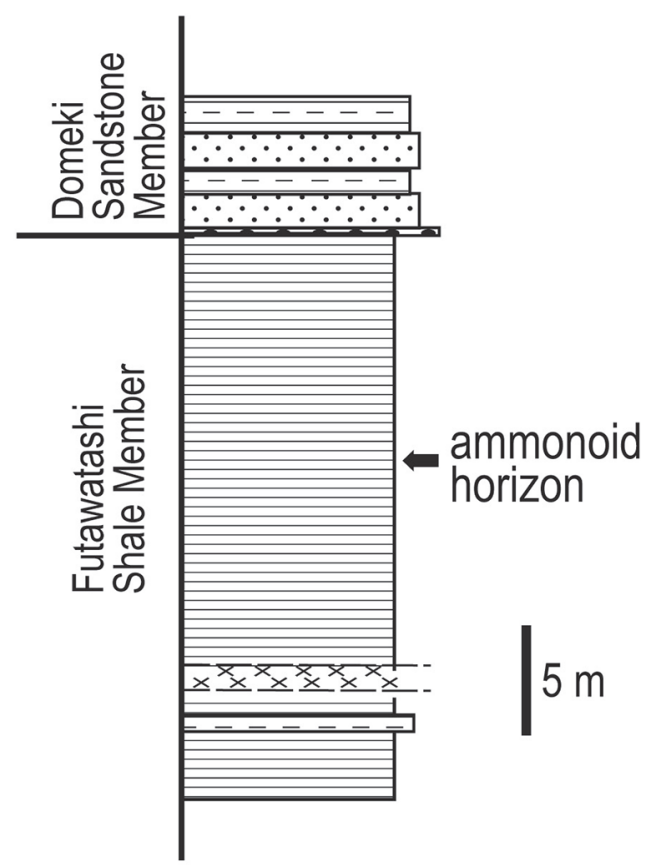

Legend

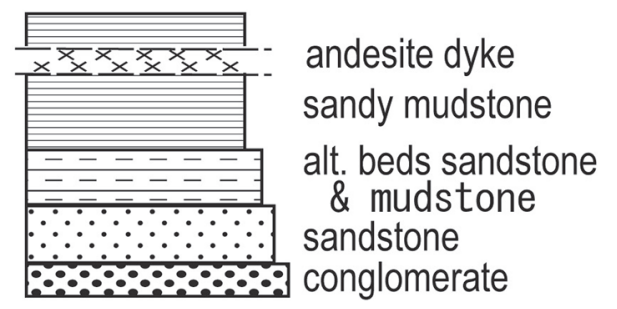

Fig. 3. Stratigraphic column of the uppermost section of the Futawatashi Shale Member at the fossil locality, west of Cape Domeki, Ajishima Island.

\section{Olcostephanus atherstoni (Sharpe, 1856)}

Fig. 4.1

Ammonites Atherstoni Sharpe, 1856, p. 196, pl. 23, fig. 1.

Rogersites tenuicostatus Imlay, 1937, p. 562, pl. 73, figs. 3-9.

Olcostephanus (Olcostephanus) atherstoni (Sharpe). Cooper, 1981, p. 182, figs. 9, 19, 24-26, 27A-D, 28-43, 143C-D, 151A. (cum synonymia)

Olcostephanus (Olcostephanus) atherstoni (Sharpe). Mourgues et al., 2015, p. 220, figs. 5-6. (cum synonymia)

Material.- A flattened, elliptically deformed specimen, IGPS coll. cat. no. 112392.

Description.- The shell attains a diameter of about $34 \mathrm{~mm}$ along the longest axis of the specimen, and the corresponding height, width and umbilical diameter are ca. 13 , ca. 14 and $9 \mathrm{~mm}$, respectively. The $H / D$ is 0.38 and $U D / D$ is 0.26 . Although the original whorl section shape is unclear due to the flattening of the specimen, it displays convex sides, which converge toward a rounded venter without remarkable ventral shoulders. The umbilical wall is steep and the umbilical shoulder is acutely rounded. The maximum shell width is at the umbilical shoulder (at the umbilical tubercle). The shell surface is ornamented by radial ribs. There are 17-18 primary ribs on the umbilical wall. They are short and straight, and swell into small rounded tubercles on the umbilical shoulder. Bundles of two or three secondary ribs arise from the tubercle and cross the flank and venter without interruption. Weak constrictions, probably three per whorl and parallel to the ribs, are also visible on the shell surface. The suture is not preserved.

Discussion.- This specimen closely resembles Rogersites tenuicostatus, a species described by Imlay (1937, p. 562, pl. 73, fig. 3-9) from northern Mexico and later incorporated by Cantú Chapa (1966) into his genus Taraisites. Both genera, Rogersites and Taraisites are currently regarded as junior synonyms of $\mathrm{Ol}$ costephanus (e.g., Aguirre-Urreta, 2013; GonzálezArreola et al., 2014; Mourgues et al., 2015). Cooper (1981), who substantially simplified the olcostephanid taxonomy, included $R$. tenuicostatus among the numerous subjective synonyms of Olcostephanus atherstoni. We fully agree with this interpretation. Although in the most typical specimens of the highly variable $O$. atherstoni show bundles of 3-5 secondary ribs, microconchs with only two ribs per bundle are not rare (Riccardi et al., 1971; Cooper, 1981).

Occurrence.- Uppermost part of the Futawatashi Shale Member of the Ayukawa Formation, Oshika Group, exposed at southeastern coast of Ajishima Island, Oshika area, Miyagi Prefecture.

Olcostephanus cf. stephanophorus (Matheron, 1878) Fig. 4.2

cf. Ammonites stephanophorus Matheron, 1878, pl. B-20, fig. 4.

Material.-An elliptically deformed, fragmental specimen, IGPS coll. cat. no. 112393.

Description. - Only about a half side of a whorl is at hand. The shell attains a diameter of about $50 \mathrm{~mm}$ along the longest axis, and the corresponding height and umbilical diameter are ca. 18 and $15 \mathrm{~mm}$, respectively. The $U D / D$ is 0.3 . The shell width is estimated to be around 


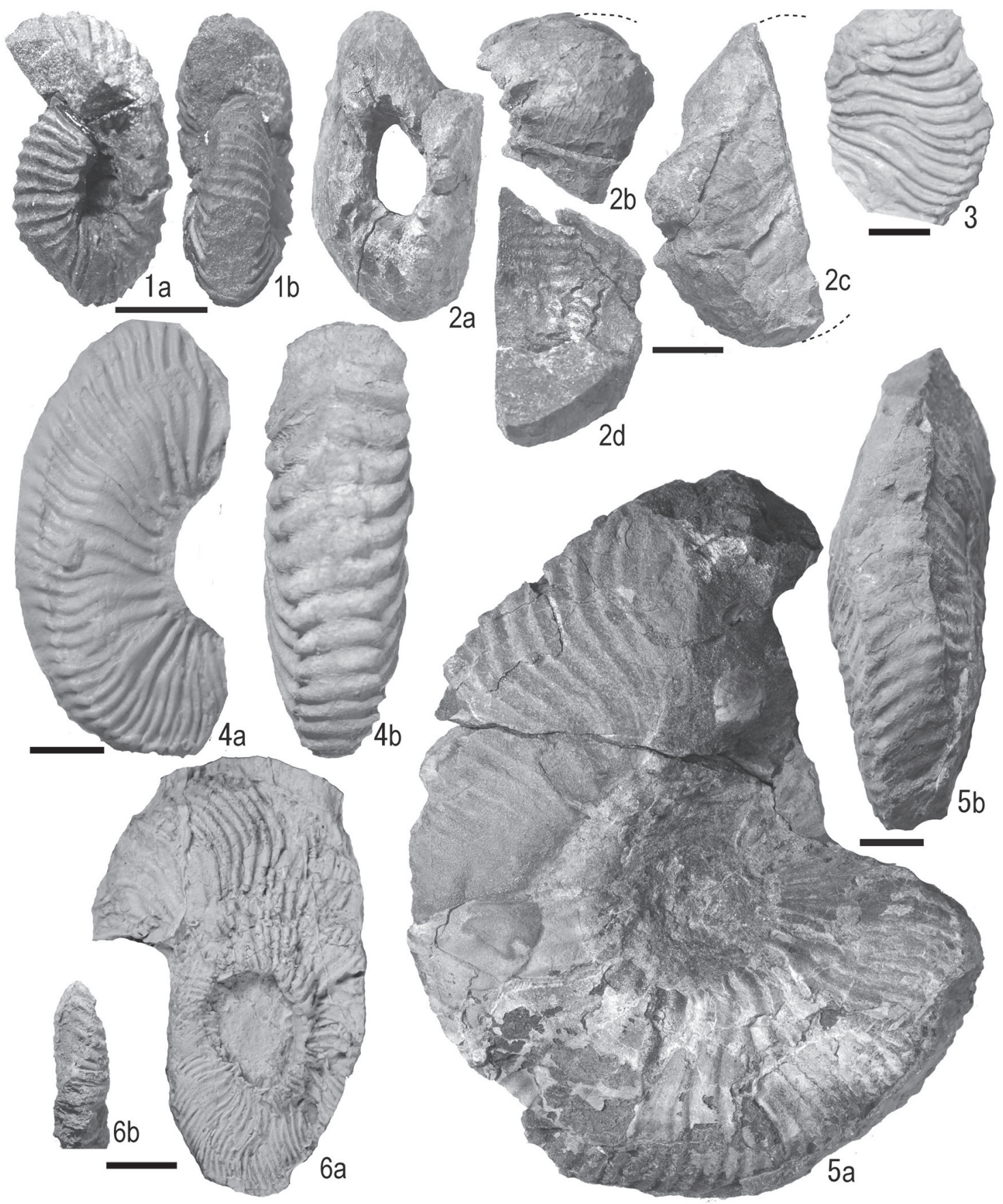

Fig. 4. Ammonoid fossils from the uppermost section of the Futawatashi Shale Member of the Ayukawa Formation at the southwestern beach between Futawatashi and Cape Domeki, Ajishima Island, Ishinomaki City, Miyagi Prefecture. 1. Olcostephanus atherstoni (Sharpe), IGPS coll. cat. no. 112392. 1a. Lateral view of the inner mold; 1b. Ventral view of the inner mold. 2. Olcostephanus cf. stephanophorus (Matheron), IGPS coll. cat. no. 112393. 2a. Lateral view of the inner mold; 2b-c. Ventral view; 2d. Dorsal view showing outer molds of the ventral ribs on the preceding volution. 3-5. Busnardoites aff. campylotoxus (Uhlig). 3. IGPS coll. cat. no. 112394, lateral view of rubber cast of the outer mold. 4. IGPS coll. cat. no. 112395. 4a. Lateral view of rubber cast of the outer mold; 4b. Ventral view of the inner mold. 5. IGPS coll. cat. no. 112397. 5a. Lateral view of the inner mold; 5b. Ventral view of the inner mold. 6. Neocomites? sp., IGPS coll. cat. no. 112396. 6a. Lateral view of rubber cast of the outer mold; $6 \mathrm{~b}$. Ventral view of inner mold of the adoral end. Scale bars are $1 \mathrm{~cm}$. 
$35 \mathrm{~mm}$. The sides are slightly convex and the venter is broadly rounded without remarkable ventral shoulders. The umbilical wall is steep with acutely rounded umbilical shoulder. The maximum shell width is at the umbilical shoulder (at the umbilical tubercle). The shell surface is ornamented only by $12-13$ primary ribs, which originate on the umbilical wall and end at the umbilical shoulder in radially elongated bullae. The rest of the shell surface on the outer whorl seems to be smooth, except for indistinct and sparse ribs on the venter (Fig. $4.2 b)$. However, the impression of dense secondary ribbing of the preceding whorl is clearly visible on the dorsal side of the preserved whorl (Fig. 4.2d). The suture is not observable.

Discussion.- Although the poor preservation of this specimen precludes an accurate taxonomic assignment, its shell parameters and ornamentation clearly correspond to the genus Olcostephanus. In particular, its cadiconic shape, with a strongly depressed section and a relatively open umbilicus, combined with the dense ribbing are characteristic of Olcostephanus stephanophorus (Matheron). This species also shows a clear trend to the fading of secondary ribs on the body chamber (Bulot and Autran, 1990; Fözy et al., 2010, fig. 3J-K). Other inflated Olcostephanus, like O. laticosta (Gerth, 1925) or extreme morphotypes of $O$. atherstoni, have a much coarser ribbing. Also in some specimens of the genus Valanginites, with a similar reniform whorl section, the secondary ribs tend to disappear in the adult stage (e.g., Kemper et al., 1981, pl. 38, fig. 7-8; Mutterlose, 1992, pl. 5, fig. 1-2); but they clearly differ from our specimen by having a much narrower, almost occluded umbilicus.

Occurrence.- Uppermost part of the Futawatashi Shale Member of the Ayukawa Formation, Oshika Group, exposed at southeastern coast of Ajishima Island, Oshika area, Miyagi Prefecture.

Family Neocomitidae Salfeld, 1921

Subfamily Neocomitinae Salfeld, 1921

Genus Busnardoites Nikolov, 1966

Type species: Ammonites desori Pictet and Campiche, 1860

Busnardoites aff. campylotoxus (Uhlig, 1902) Fig. 4.3- 4.5

aff. Hoplites campylotoxus Uhlig, 1902, p. 49, pl. 4, figs. 1-3.

Thurmannia campylotoxa (Uhlig, 1902). Sayn, 1907, p. 42, pl. 5, fig. 12.

Busnardoites campylotoxus (Uhlig, 1902). Nikolov,
1977, p. 112, pl. 4, fig.1.

Material.- Three specimens, IGPS coll. cat. nos. 112394, 112395, and 112397.

Description. - Three outer and/or inner molds of fragmental specimens are examined. They are elliptically deformed. The maximum shell diameter along the deformed longest axis of the largest specimen (IGPS coll. cat. no. 112397) attains about $117 \mathrm{~mm}$ and that of the smallest specimen (IGPS coll. cat. no. 112395) is about $64 \mathrm{~mm}$. The coiling is moderately involute $(U D / D=$ 0.21-0.29). The whorl section is compressed, subrectangular. Flanks are subparallel, slightly convex, and the maximum shell width is at the middle part of the flanks ( $W / D=0.21-0.23$ in the deformed state). The ventral region is narrow and flattened, with sharp ventrolateral shoulders. The umbilical wall, although it is not well preserved, is probably steep with a sharp umbilical shoulder. The suture is not preserved.

The shell is ornamented by strong, falcoid ribs. They arise singly, or occasionally in pairs, from well developed, conical umbilical tubercles. Most of the ribs bifurcate at the middle of the flanks, and there are also some intercalated ribs, more frequent in the adoral part of the shell, where they start in the lower third of the flank. Primary ribs (13-15 per half whorl) are prorsiradiate, and somewhat coarser than the concave secondary ones. All the ribs bear distinct ventrolateral tubercles and cross transversally the venter with a slight weakening in their strength.

Discussion.- Both the shell form (especially the compressed whorl section with subparallel flanks) and the ornamental pattern (bifurcate, falcoid ribs with conspicuous umbilical and ventrolateral tubercles) of the Japanese specimens are very similar to those shown by typical Mediterranean specimens of Busnardoites campylotoxus, especially the most finely ribbed morphotypes, like those figured by Sayn (1907, pl. 5, fig. 12: as Thurmannia) or Nikolov (1977, pl. 4, fig.1). However, Mediterranean forms have a slightly more evolute coiling $(U D / D=0.28-0.36)$, and a narrow smooth ventral band that, only at the end of the adult stage, is traversed by the ribs (Nikolov, 1977). These differences could merely be due to geographic morphologic variability. But this is difficult to assess and a strict identification cannot be established.

Occurrence.- Uppermost part of the Futawatashi Shale Member of the Ayukawa Formation, Oshika Group, exposed at southeastern coast of Ajishima Island, Oshika area, Miyagi Prefecture. 
Genus Neocomites Uhlig, 1905

Type species: Ammonites neocomiensis Orbigny, 1841

\section{Neocomites? sp.}

Fig. 4.6

Material.- Outer mold and parts of the inner mold of an elliptically deformed specimen (IGPS coll. cat. no. 112396).

Description.- The maximum shell diameter of this specimen is about $62 \mathrm{~mm}$ (measured along the longest deformed axis). Moderately involute shell ( $U D / D=$ 0.26 ) has subtrapezoidal, compressed whorl section. The flanks are slightly convex and converge in a gently arched ventral region. The umbilical wall is high and vertical, with a sharp shoulder.

The ornamentation consists of rather fine, dense, sinuous ribs. They arise, singly or in pairs, from small umbilical bulges ( $\sim 20$ per half whorl), and many of them branch at the lower third to the middle of the flank (somewhat higher in the final preserved part of the shell). The ribs project forward on the outer flank and traverse the venter without weakening in their relief and drawing a marked adoral convexity.

Discussion.- The structure of the shell and the ribbing style of this specimen certainly remind of the genus Neocomites. It resembles, in particular, some finely ornamented Mediterranean species of this genus, like Neocomites subtenuis Sayn, 1907, Neocomites subflucticulus (Reboulet, 1996) and Necomites flucticulus Thieuloy, 1977. There are, however, some significant differences. In $N$. subtenuis, a species from the lower Valanginian (Ettachfini, 2004; Company and Tavera, 2015), the coiling is more involute, and the ribs tend to fade out on the flank. Both $N$. subflucticulus and $N$. flucticulus, respectively from the uppermost Valanginian and the lowermost Hauterivian (Reboulet, 1996), show, unlike our specimen, frequent intercalated ribs but very rare bifurcated ribs. In the species of the genus Neocomites, the ribs tipically end in small ventrolateral tubercles, leaving a smooth and flattened siphonal band throughout most of the ontogeny; only in the adoral half of the body chamber, the venter becomes rounded and, in some species, is traversed by the ribs. All these differences cast uncertainty on the attribution of the Japanese form to the genus Neocomites. Most probably, our specimen belongs to a not yet described endemic taxon.

Occurrence.- Uppermost part of the Futawatashi Shale Member of the Ayukawa Formation, Oshika Group, exposed at southeastern coast of Ajishima Island, Oshika area, Miyagi Prefecture.

\section{Discussion}

\subsection{Age of the ammonoid fauna and the age of the Ayukawa Formation}

As described above, the Ayukawa Formation is subdivided, from bottom to top, into the Kiyosaki Sandstone, the Kobitawatashi Sandstone and Shale, the Futawatashi Shale, and the Domeki Sandstone members (Takizawa et al., 1974). The ammonite assemblage studied in this paper comes from the uppermost part of the Futawatashi Shale Member and is composed of Olcostephanus atherstoni, O. cf. stephanophorus, Busnardoites aff. campylotoxus, and Neocomites? sp.

Olcostephanus atherstoni is a very widespread species, present not only throughout the Tethyan Realm, both in the Mediterranean-Caucasian and Indo-Pacific subrealms (sensu Lehmann et al., 2015), but also in the neighboring areas of the Boreal Realm. It also has a rather long stratigraphic distribution (Bulot and Thieuloy, 1995; Company and Tavera, 2015; Mourgues et al., 2015), ranging from the middle part of the lower Valanginian to the lower part of the upper Valanginian (i.e., Neocomites neocomiensiformis Zone to Saynoceras verrucosum Zone in the current standard Mediterranean zonation proposed by Reboulet et al., 2018). We have already mentioned that the specimen from the Ayukawa Formation closely resembles those described by Imlay (1937) as Rogersites tenuituberculatus. The stratigraphic position of these Mexican forms is significant, since they were found together with Valanginites tijerensis Imlay, a species very close to (and probably synonym of) Valanginites dolioliformis (Roch, 1930), which characterizes the upper part of the Neocomites neocomiensiformis Zone in the Mediterranean region (Company and Tavera, 2015).

The geographic distribution of Olcostephanus stephanophorus seems to be more restricted. It has hitherto been reported in the North Mediterranean area and, more doubtfully, from Pakistan. Its stratigraphic range encompasses the middle and upper part of the lower Valanginian (i.e., the Neocomites neocomiensiformis and Karakaschiceras inostranzewi zones) (Bulot and Thieuloy, 1995; Company and Tavera, 2015).

Busnardoites campylotoxus is a relatively common species throughout the Mediterranean region, from Morocco to Georgia, and has been claimed to occur also in Pakistan and Madagascar. This species has been widely used in the past to characterize the upper half of the lower Valanginian. Nevertheless, its actual stratigraphic range is much shorter and confined to the upper part of the Neocomites neocomiensiformis Zone, where it coex- 
ists with Valanginites dolioliformis (Bulot and Thieuloy, 1995; Ettachfini, 2004; Company and Tavera, 2015).

It can be concluded, therefore, that the age of the ammonoid fauna from the uppermost Futawatashi Member of the Ayukawa Formation very likely corresponds to the upper part of the Neocomites neocomiensiformis Zone (middle early Valanginian) (Fig. 5).

A few more ammonites were previously recorded from the Ayukawa Formation by Takahashi (1969) and Takizawa (1970). Takahashi (1969) mentioned the presence of Berriasellinae and Neocomitinae near Kanayama, north of Ayukawa (probably from the lower part of the Futawatashi Shale Member). Onuki (1969) attributed these Takahashi's specimens to Lyticoceras sp. and Sarasinella aff. hyatti (Stanton), but no further information was provided and whereabouts of these specimens are unknown. On the other hand, Sato and Takizawa (in Takizawa, 1970) described and figured Berriasella sp., Thurmanniceras cf. isokusense (Kobayashi and Fukada, 1947) and Kilianella sp. from several outcrops of the Ayukawa Formation. These ammonites are relevant to the discussion on the age of the Ayukawa Formation and their taxonomic assignment deserves to be reconsidered.

The specimen determined as Berriasella sp. by Sato and Takizawa (in Takizawa, 1970, pl. 1, fig. 1) was collected near Yokone (Fig. 2, locality A) in the lower part of the Kobitawatashi Sandstone and Shale Member. It is moderately involute, with slightly sinuous, fasciculate and irregularly bifurcate ribs, which vanish on the flanks in the adult stage. These features lead us to include this specimen in the genus Tirnovella, with closest affinities to the species T. occitanica (Pictet, 1867) and T. subalpina (Mazenot, 1939), both characteristic of the middle Berriasian.

The small specimen from the lower part of the Futawatashi Shale Member near Kanayama, north of Ayukawa, attributed by Sato and Takizawa (pl. 1, fig. 2) to Thurmaniceras cf. isokusense is, in fact, comparable in every respect to the juvenile stages of Neocomites premolicus Sayn, 1907. This species characterizes the lowermost Valanginian (lower part of the Thurmanniceras pertransiens Zone) in the Mediterranean region.

The third specimen (Kilianella sp. in Takizawa, 1970, pl. 1, fig. 3) was found not in situ (but most probably from the lower part of the Futawatashi Shale Member) near Futawatashi (Fig. 2, Locality B). Its evolute coiling and its distinctive ornamentation, with strong constrictions, and coarse, rursiradiate and often simple ribs, allow to refer, without much doubt, this ammonite to Kilianella chamalocensis Mazenot, 1939, a species known from the uppermost Berriasian (Tirnovella alpil- lensis Zone) to lowermost Valanginian (Thurmanniceras pertransiens Zone) in the North Mediterranean area (Aguado et al., 2000).

All these data suggest that the age of the Ayukawa Formation is Berriasian-early Valanginian, except for its lowermost part (Kiyosaki Sandstone Member). The Domeki Sandstone Member, uppermost member of the Ayukawa Formation overlying the Futawatashi Shale Member, has no fossils, but also considered to be early Valanginian, because it is composed mainly of fluvialdeltaic coarse sandstones, which are considered to have deposited at high sedimentation rate. The Berriasian/Valanginian boundary could be tentatively correlated with the boundary between the Kobitawatashi Sandstone and Shale Member and the Futawatashi Shale Member (Fig. 5).

\subsection{The timing of the Early Cretaceous volcanic ac- tivity in the South Kitakami Belt}

In the South Kitakami Belt, no volcanic sediments have been known from the Jurassic strata, except for their topmost part. In the Oshika Peninsula, MiddleUpper Jurassic Tsukinoura and Oginohama formations have no volcanic sediments. The volcanic activity started at latest Jurassic to earliest Cretaceous, because the Ayukawa Formation, including it lowermost part (Kiyosaki Sandstone Member), intercalates some dacitic to rhyolitic tuff layers. But, these tuff layers are all very thin, and the violent volcanic activity was not until the deposition of the Yamadori Formation, which unconformably rest on the Ayukawa Formation and consists of huge amount of andesitic to basaltic volcanic and volcaniclastic rocks. Takizawa et al. (1974) considered that the age of the Yamadori Formation (the stage of the heavy volcanic activity) is to be late Valanginian to Hauterivian, based on their estimation that the upper part of the underlying Ayukawa Formation would be correlated with the Valanginian. The present discovery of the early Valanginian ammonoid fauna from the upper part of the Ayukawa Formation secured this correlation (Fig. 5).

In the Karakuwa area, which belongs to the same subbelt (Karakuwa-Oshika Subbelt) with the Oshika area, thick volcanic-volcaniclastic rocks (the Kanaegaura Formation) cover the lowermost Cretaceous Isokusa and Nagasaki formations. The upper parts of the Isokusa and Nagasaki formations are correlated with the Valanginian by ammonoids (Takahashi, 1973). Based on the radiolarians, Nara et al. (1994) correlated the Isokusa and Nagasaki formations with the upper Valanginian, but, in reviewing this radiolarian fauna, Taketani (2013) considered their age as Berriasian to early Valanginian. 


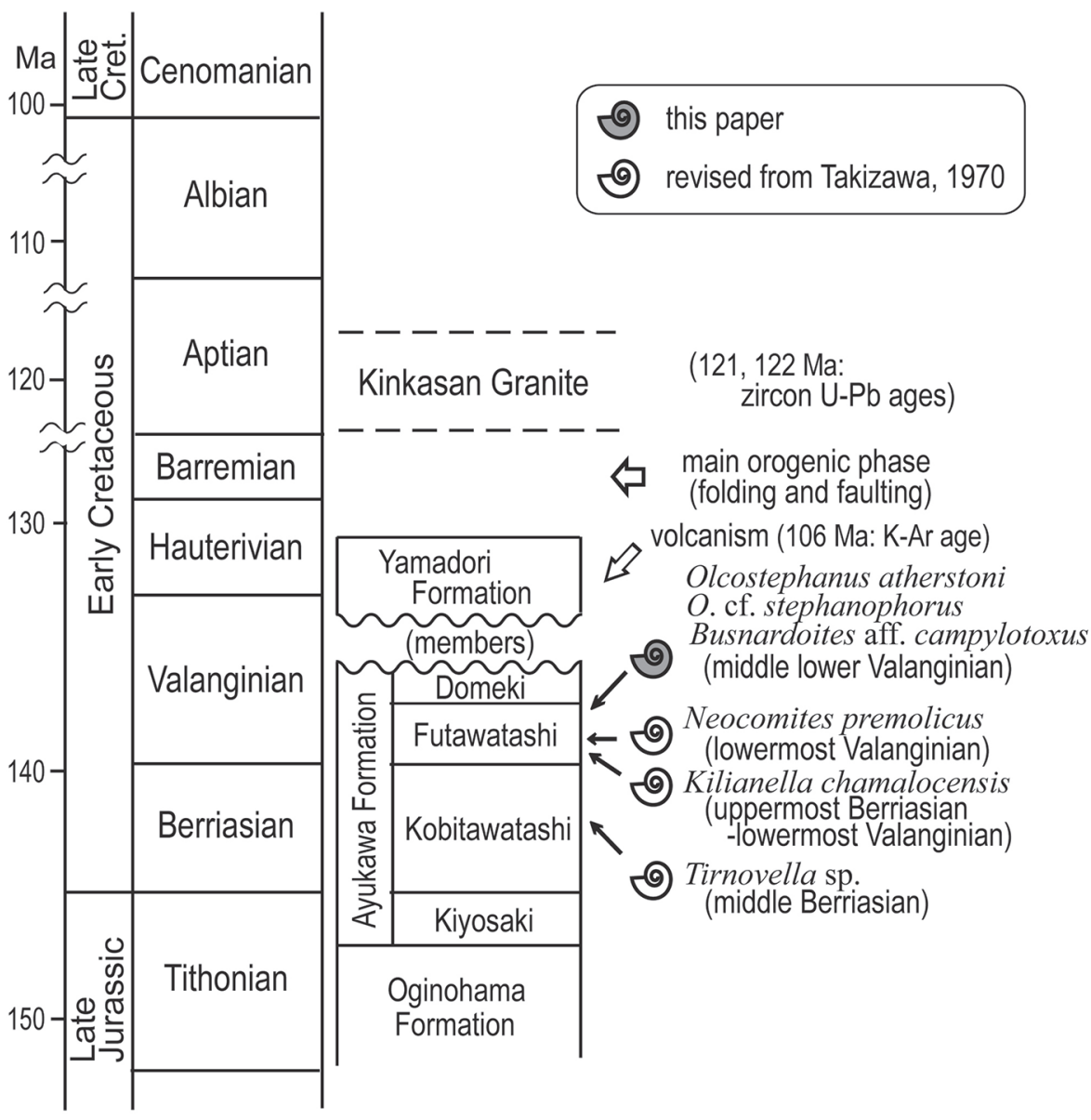

Fig. 5. Stratigraphic correlation of the uppermost Jurassic to Lower Cretaceous formations in the Oshika Area, South Kitakami Belt, and the timing of tectonic events.
The upper part of the Kanaegaura Formation is intercalated with the Yokonuma Formation (Nara et al., 1994; Tsuchiya et al., 1997). The latter yields an ammonoid Crioceratites ishiwarai (Yabe and Shimizu, 1925), the age of which is considered to be late Hauterivian (Obata and Matsumoto, 1977; Obata, 1988). Thus, the upper part of the Kanaegaura Formation is correlated with the upper Hauterivian and its top part probably ranges up to the Barremian (Nara et al., 1994; Tsuchiya et al., 1997).

According to Taketani (2013), there is no significant difference between the ages of the Isokusa and Nagasaki formations in the Karakuwa area and that of the Ayukawa Formation in the Oshika area. However, there are two ideas on the stratigraphic relationship between the Isokusa and Nagasaki formations and the Kanaegaura Formation. Nara et al. (1994) considered that the Kanaegaura Formation rests unconformably on the Isokusa and Nagasaki formations, whereas Tsuchiya et al. (1997) stressed that the lowermost part of the Kanaegaura Formation is contemporaneous with the upper part of the Isokusa and Nagasaki formations. In the latter case, the starting time of Early Cretaceous intense volcanism in the Karakuwa area is thought to be early
Valanginian, and differ from that in the Oshika area, even though they are in the same tectonic belt. This problem remains to be solved in the future.

\section{Conclusions}

1. The uppermost part of the Futawatashi Shale Member of the Ayukawa Formation yields ammonoids Olcostephanus atherstoni, O. cf. stephanophorus, Busnardoites aff. campylotoxus and Neocomites? sp., and correlatable with the upper part of the Neocomites neocomiensiformis Zone, which occupies the middle part of the lower Valanginian (Lower Cretaceous).

2. Based on the re-examination of previously reported ammonoids from the lower to middle part of the Ayukawa Formation, the boundary between the Kobitawatashi Sandstone and Shale Member and the Futawatashi Shale Member is roughly correlated with the Berriasian/Valanginian boundary.

3. The intense volcanic activity in the Oshika Area, represented by the deposition of the Yamadori Formation, started somewhere from the late Valanginian to the early Hauterivian. 


\section{Acknowledgements}

We gratefully acknowledge Osamu Koseki, Takashi Hamada and Akira Koide for their cooperation and leadership role in the early stage of this study. Deep appreciation is also due to Yutaro Suzuki and members of the Michinoku Amateur Paleontologist' Club for their assistance in the field survey, and Yasunari Shigeta for his help with the literature. The manuscript was greatly improved by the constructive reviews of Yojiro Taketani and an anonymous reviewer.

\section{References}

Agassiz, L., 1847, Introduction to the Study of Natural History, in a Series of Lectures Delivered in the Hall of the College of Physicians and Surgeons, New York. Greeley \& McElrath, 58p.

Aguado, R., Company, M. and Tavera, J. M., 2000, The Berriasian/Valanginian boundary in the Mediterranean region: new data from the Cravaca and Cehegín sections, SE Spain. Cretaceous Res., 21, 1-21.

Aguirre-Urreta, M. B., 2013, Amonoideos del ValanginianoHauteriviano de la Cuenca Neuquina: Sistemática, Bioestratigrafía y Paleobiogeografía. Tesis Doctoral, Univ. Buenos Aires, 269p. ${ }^{1)}$

Bulot, L. and Autran, G., 1990, Révision des types et figures de la collection Matheron 1. Olcostephanus stephanophorus (Matheron, 1878). Mésogée, 49 (1989), 15-19. ${ }^{2)}$

Bulot, L. and Thieuloy, J. P., 1995, Les biohorizons du Valanginien du Sud-Est de la France: un outil fondamental pour les corrélations au sein de la Téthys occidentale. Géol. Alpine, 20, 15-41.2)

Cantú Chapa, A., 1966, Se propone una nueva subdivisión de la familia Olcostephanidae (Ammonoidea) del Cretácico inferior (Taraisitinae subfam. nov. y Taraisites gen. nov.). Ingen. Petrol., 6 (12), 15-17. ${ }^{1)}$

Company, M. and Tavera, J. M., 2015, Lower Valanginian ammonite biostratigraphy in the Subbetic Domain (Betic Cordillera, southeastern Spain). Carnets de Géologie [Notebooks on Geology], 15, 71-88.

Cooper, M., 1981, Revison of the late Valanginian Cephalopoda from the Sundays River Formation of South Africa, with special reference to the genus Olcostephanus. Ann. South African Mus., 83, 147-366.

Editorial Committee of Tohoku, Regional Geology of Japan, ed., 1989, Regional Geology of Japan, Part 2, Tohoku. Kyoritsu Shuppan, 239p. ${ }^{3) *}$

Ehiro, M., 2017, Chapter 3.1. Pre-Neogene tectonic history. In Geological Society of Japan, ed., Regional Geology of Japan, Vol. 2, Tohoku District, Asakura Publ., 105-119.3."

Ettachfini, M., 2004, Les ammonites neocomiennes dans 1'Atlas Atlantique (Maroc). Biostratigraphie, paléontologie, paléobiogéographie et paléoécologie. Strata (Sér. 2), 43, 1-225. ${ }^{4}$

Fözy, I., Janssen, N. M. M., Price, G. D., Knauer, J. and Pálfy, J., 2010, Integrated isotope and biostratigraphy of a Lower Cretaceous section from the Bakony Mountains (Transdanubian Range, Hungary): A new Tethyan record of the Weissert event. Cretaceous Res., 31, 525-545.

Gerth, E., 1925, La fauna neocomiana de la Cordillera Argentina en la parte meridional de la provincia de Mendoza. Act. Acad. Nacion. Ciencias, 9, 57-132. ${ }^{1)}$

González-Arreola, C., Barragán, R. and Moreno-Bedmar, J. A., 2014, Olcostephanidae (Ammonoidea) from the upper Valanginian Taraises Formation (Durango State, Mexico).
Cretaceous Res., 49, 55-62.

Hanai, T., Obata, I. and Hayami, I., 1968, Notes on the Cretaceous Miyako Group. Mem. Nat. Sci. Mus., 1, 20-28. ${ }^{5}$

Haug, E., 1910, Période Crétacé. In Haug, E., ed., Traité de Géologie 2. Les Périodes Géologiques 2, Colin, 11531398. ${ }^{2)}$

Igi, S., Katada, M., Takizawa, F. and Abe, T., 1974, Gabbroic complexes in the Ojika peninsula and Kasagai islet, Miyagi Prefecture, Japan. J. Geol. Soc. Japan, 80, 107-114.

Imlay, R., 1937, Lower Neocomian fossils from the Miquihuana region, Mexico. J. Paleontol., 11, 552-574.

Kawano, Y. and Ueda, Y., 1964, K-A dating on the igneous rocks in Japan (1). J. Japan. Assoc. Mineral. Petrol. Econ. Geol., 51, 127-148.

Kemper, E., Rawson, P. F. and Thieuloy, J. P., 1981, Ammonites of Tethyan ancestry in the early Lower Cretaceous of northwest Europe. Palaeontology, 24, 251-311.

Kimura, T., 1979, Japanese Island: the Process of its Formation, Vol. 2B. Kokon Shoin, 578p. ${ }^{3) *}$

Kobayashi, T., 1941, The Sakawa orogenic cycle and its bearing on the origin of the Japanese Islands. J. Fac. Sci., Imp. Univ. Tokyo, Sec. 2, 5, 219-578.

Kobayashi, T. and Fukada, A., 1947, On the occurrence of Discosphinctes in the Kitakami Mountains in Nippon. Japan. J. Geol. Geogr., 20, 55-57.

Koseki, O., Hamada, T., Hanamatsu, S., Koide, A. and Suzuki, Y., 1988, Occurrence of fossil Crustacea from Lower Cretaceous (Valanginian) Futawatashi Shale Member, Aji-island, Oshika-town, Miyagi Prefecture, Northeast Japan. 95th Annu. Meet. Geol. Soc. Japan, Abstr., 194. ${ }^{3)}$

Koseki, O., Hamada, T., Hanamatsu, S., Koide, A. and Suzuki, Y., 1991, Early Cretaceous crustacean fossils from Aji-island, Oshika-town, Miyagi Prefecture. 1991 Annu. Meet. Palaeont. Soc. Japan, Abstr., 98. ${ }^{3} *$

Kubo, K., 1977, Petrological Study on the Ojika Gabbroic Complex, Kitakami Mountains, Northeast Japan. J. Geol. Soc. Japan, 83, 763-782.

Lehmann, J., Ifrim, C., Bulot, L. and Frau, C., 2015, Paleobiogeography of Early Cretaceous ammonoids. In Klug, C., Korn, D., De Baets, K., Kruta, I. and Mapes, R. H., eds., Ammonoid Paleobiology: From Macroevolution to Paleogeography, Springer, 229-257.

Matheron, P., 1878-1880, Recherches Paléontologiques dans le Midi de la France. Marseille, 12p. ${ }^{2}$.

Matsumoto, T., 1953, The Cretaceous System in the Japanese Islands. Japan. Soc. Prom. Sci., 324p.

Matsumoto, T., 1963, The Cretaceous. In Takai, F., Matsumoto, T. and Toriyama, R., eds., Geology of Japan, Univ. Tokyo Press, 99-128.

Mazenot, G., 1939, Les Palæhoplitidae tithoniques et berriasiens du Sud-Est de la France. Mém. Soc. Géol. France (Nouv. Sér.), 41, 1-303. ${ }^{2)}$

Mourgues, F. A., Bulot, L. G. and Frau, C., 2015, The Valanginian Olcostephaninae Haug, 1910 (Ammonoidea) from the Andean Lower Cretaceous Chañarcillo Basin, Northern Chile. Andean Geol., 42, 213-236.

Mutterlose, J., 1992, Die Unterkreide-Aufschlüsse (BerriasHauterive) im nördlichen Wiehengebirgsvorland (NDeutschland). Geol. Paläontol. Westfalen, 21, 39-113. ${ }^{6)}$

Nara, C., Taketani, Y. and Minoura, K., 1994, Jurassic-Cretaceous stratigraphy in the Kesennuma and Karakuwa area of southern Kitakami Mountains, Northeast Japan. Bull. Fukushima Mus., 8, 29-63. ${ }^{5}$

Neumayr, M., 1875, Über Kreideammonitiden. Sitz. Kai. Akad. Wiss., Math.-Natur. Classe, 71, 639-693. $\left.{ }^{6}\right)$

Nikolov, T., 1966, New genera and subgenera of ammonites of family Berriasellidae. Compt. Rend. l'Acad. Bulgare Sci., 19, 639-642. 
Nikolov, T., 1977, On the ammonite genus Busnardoites Nikolov, 1966 (Berriasellidae, Lower Cretaceous). Geol. Balcanica, 7 (4), 107-118.

Obata, I., 1988, Cretaceous formations in Northeast Japan. Earth Sci. (Chikyu Kagaku), 42, 385-395.)

Obata, I. and Matsumoto, T., 1977, Correlation of the Lower Cretaceous formations in Japan. Sci. Rep. Depart. Geol., Kyushu Univ., 12, 165-179.)

Onuki, Y., 1969, Geology of the Kitakami Massif, Northeast Japan. Contrib. Inst. Geol. Paleontol. Tohoku Univ. 69, 1-239.)

Orbigny, A. d' , 1840-1842, Paléontologie Française. Description Zoologique et Géologique de Tous les Animaux Mollusques et Rayonnés Fossiles de France. Terrains Crétacés. Tome Premier. Paris, 662p. ${ }^{2}$

Osozawa, S., Usuki, T., Usuki, M., Wakabayashi, J. and Jahn, B.-M., 2019, Trace elemental and Sr-Nd-Hf isotopic compositions, and $\mathrm{U}-\mathrm{Pb}$ ages for the Kitakami adakitic plutons: Insights into interactions with the early Cretaceous TRT triple junction offshore Japan. J. Asian Earth Sci., 184, 103968. doi: 10.1016/j.jseaes.2019.103968

Pictet, F. J., 1867, Études paléontologiques sur la faune à Terebratula diphyoides de Berrias (Ardèche). In Pictet, F. J., ed., Mélanges Paléontologiques, Genève, 43-130.2)

Pictet, F. J. and Campiche, G., 1858-1860, Description des Fossiles du Terrain Crétacé des Environs de Sainte-Croix. Première Partie. J. Kessmann and H. Georg, Genève, 380p. ${ }^{2)}$

Reboulet, S., 1996, L'evolution des ammonites du ValanginienHauterivien inférieur du bassin vocontien et de la plateforme provençal (Sud-Est de la France): relations avec la stratigraphie séquentielle et implications biostratigraphiques. Doc. Lab. Géol. Lyon, 137 (1995), 1-371.2)

Reboulet, S., Szives, O., Aguirr-Urreta, M., Barragán, R., Company, M., Frau, C.,... Mitta, V. V., 2018, Report on the 6th International Meeting of the IUGS Lower Cretaceous Ammonite Working Group, the Kilian Group (Vienna, Austria, 20th August 2017). Cretaceous Res., 91, 100-110.

Riccardi, A. C., Westermann, G. E. G. and Levy, R., 1971, The Lower Cretaceous Ammonitina Olcostephanus, Leopoldia, and Favrella from west-central Argentina. Palaeontographica, Abt. A, 136, 83-121.

Roch, E., 1930, Études géologiques dans la région méridionale du Maroc occidental. Notes Mém. Serv. Mines Carte Géol. Maroc, 9, 1-542.)

Salfeld, H., 1921, Kiel- und Furchenbildung auf der Schalenaussen-seite der Ammonoideen in ihrer Bedeutung für die Systematik und Festlegung von Biozonen. Zentralbl. Mineral. Geol. Paläeontol., 1921, 343-347. .)

Sayn, G., 1901-1907, Les ammonites pyriteuses des Marnes valangiennes du Sud-Est de la France. Mém. Soc. Géol. France, Paléontol., 23, 1-66. ${ }^{2)}$

Sharpe, D., 1856, Description of fossils from the secondary rocks of Sunday River and Zwartkop River, South Africa, collected by Dr. Atherstone and A. G. Bain, Esq. Trans. Geol. Soc. London (2nd ser.), 7, 193-203.

Shibata, K., Matsumoto, T., Yanagi, T. and Hamamoto, R., 1978, Isotopic ages and stratigraphic control of Mesozoic igneous rocks in Japan. In Cohee, G. V., Glaessner, M.F. and Hedberg, H. D., eds., Contributions to the Geologic Time Scale, Am. Assoc. Pet. Geol., Stud. Geol., 8, 143-164.

Steinmann, G., 1890, Unterfam. Perisphinctinae. In Steinmann, G. and Ludwing, D., eds., Elemente der Paläontologie, Wilhelm Engelmann, 441-448. ${ }^{6}$

Takahashi, H., 1969, Stratigraphy and ammonite fauna of the Jurassic System of the Southern Kitakami Massif, Northeast Japan. Sci. Rep. Tohoku Univ., 2nd Ser., 41, 1-93.

Takahashi, H., 1973, The Isokusa Formation and its late Upper Jurassic and early Lower Cretaceous ammonite fauna. Sci.
Rep. Tohoku Univ., 2nd Ser., Spec. Vol., 6, 319-336.

Taketani, Y., 2013, Lowermost Cretaceous radiolarian assemblage from the Koyamada Formation of the Somanakamura Group, Northeast Japan. Bull. Fukushima Mus., 27, 1-24. ${ }^{5}$

Takizawa, F., 1970, Ayukawa Formation of the Ojika Peninsula, Miyagi Prefecture, Northeast Japan. Bull. Geol. Surv. Japan, 21, 567-578.

Takizawa, F., 1977, Some aspects of the Mesozoic sedimentary basins in the South Kitakami Belt, Northeast Japan. Monogr. Assoc. Geol. Collab. Japan, 20, 61-73.

Takizawa, F., Isshiki, N. and Katada, M., 1974, Geology of the Kinkasan District. Quadrangle Series, Scale 1: 50,000. Geol. Surv. Japan. 62p. ${ }^{5}$

Thieuloy, J. P., 1977, La Zone à Callidiscus du Valanginien supérieur vocontien (Sud-Est de la France). Lithostratigraphie, ammonitofaune, limite Valanginien-Hauterivien, corrélations. Géol. Alpine, 53, 83-143.')

Tsuchiya, N., 2017, Chapter 6. Cretaceous to Paleogene igneous rocks. In Geological Society of Japan, ed., Regional Geology of Japan, Vol. 2, Tohoku, Asakura Publ., 283-328. ${ }^{3) *}$

Tsuchiya, N., Chiba, T., Takahashi, K. and Wada, M., 1997, Occurrence of the Lower Cretaceous volcanic rocks from the Oshima Island, Kesennuma, south Kitakami Mountains, Japan. Annu. Rep. Fac. Educ., Univ. Iwate, 57, 53-73.5)

Tsuchiya, N., Takeda, T., Adachi, T., Nakano, N., Osanai, Y. and Adachi, Y., 2015, Early Cretaceous adakitic magmatism and tectonics in the Kitakami Mountains, Japan. Japan. Mag. Mineral. Petrol. Sci., 44, 69-90.5)

Uhlig, V., 1902, Ueber die Cephalopodenfaunen der Teschener und Grodischter Schichten. Denk. math. naturw. Kl. k. Akad. Wiss., Vienne, 72, 1-87, pls. 1-9. ${ }^{6}$

Uhlig, V., 1905, Einige Bemerkungen über die Ammonitengattung Hoplites Neumayr. Sitz. Math.-Naturw. Kl. Kais. Akad. Wiss., 114, 591-636.6)

Yabe, H. and Shimizu, S., 1925, A new Cretaceous ammonite, Crioceras ishiwarai, from Oshima, province of Rikuzen. Japan. J. Geol. Geogr., 4, 85-87.

1) : in Spanish

2) $:$ in French

3) : in Japanese

${ }^{4)}:$ in French with English abstract

${ }^{5)}$ : in Japanese with English abstract

${ }^{6)}:$ in German

* English translation from the original written in Japanese

\section{用語対比}

Ajishima: 網地島

Ayukawa: 鮎川

Domeki: ドウメキ

Futawatashi: 長渡

Hashiura: 橋浦

Isokusa: 磯草

Kanaegaura: 鼎ヶ浦

Kanayama: 金山

Karakuwa: 唐桑

Kesennuma: 気仙沼

Kinkasan: 金華山

Kiyosaki: 清崎

Kobitawatashi: 小長渡

Nagasaki: 長崎

Ofunato: 大船渡

Oginohama: 荻の浜

Oshika (Ojika): 牡鹿

Shizugawa: 志津川

Soma: 相馬

Tsukinoura: 月の浦

Yamadori: 山鳥 
Yokone: 横根

Yokonuma: 横沼
(著者の貢献)

本研究において, 永広は試料採集, 原稿執筆と総括を担当. Company は主としてアンモノイドの記載と年代論の執筆, 高泉 および花松は野外調査および試料採集に関わる部分を担当.

(要 旨)

Ehiro M., Company, M., Takaizumi, Y. and Hanamatsu, S., 2020, Geological age of the Ayukawa Formation (Oshika Group) in the South Kitakami Belt, Northeast Japan based on the ammonoids. J. Geol. Soc. Japan, 126, 563-574. （永広昌之・Miguel Company・高泉幸浩・花松俊一, 2020, 南部北上帯の牡鹿層群鮎川層のアンモノイドに もとづく地質年代. . 地質雑, 126, 563-574.)

南部北上帯牡鹿地域の網地島に分布する最上部ジュラ系〜下部白亜系鮎川層の長渡頁岩 部層最上部から 4 種のアンモノイド, Olcostephanus atherstoni, O. cf. stephanophorus, Busnardoites aff. campylotoxus およびNeocomites? sp. を記載した. これらのアンモノ イドから, 長渡頁岩部層最上部は下部白亜系下部バランギニアン階の中部 (Neocomites neocomiensiformis Zone) に対比される. 従来報告されていた鮎川層下部一中部産のアン モノイドの再検討にもとづけば, 小長渡砂岩頁岩部層と長渡頁岩部層の境界はほぼベリア シアン / バランギニアン境界に相当する，鮎川層の最上部を占める，長渡頁岩部層の上位 のドウメキ砂岩部層は陸成層でその堆積速度は速いと考えられるので, 鮎川層の上限は下 部バランギニアン階と考えられ，したがって，鮎川層を不整合に覆う山鳥層で示される激 しい火山活動の開始，すなわち“大島造山運動”の開始は後期バランギニアン期からオーテ リビアン期のどこかと考えられる

科学論文では, 学説の検証可能性を保証することが重要です. そのため, 地質学雑誌掲載論文には, 重 要な証拠となった試料がごこで得られたかを示しているものがあります。言うまでもないことですが, 見学や採取を行う場合, 各自の責任において地権者や関係官庁への連絡と許可の取得の必要があること にご注意下さい。詳しくは，以下のサイトをご覧ください.

http://www.geosociety.jp/publication/content0073.html 